\title{
ETIKA BISNIS ISLAM DALAM IMPLEMENTASI TEKNOLOGI NEUROMARKETING PADA STRATEGI PEMASARAN
}

\author{
Kisti Nur Aliyah \\ Universitas Islam Negeri Sunan Ampel Surabaya \\ e-mail: kistyalkahfi@gmail.com
}

\begin{abstract}
Over time, marketing activities are also developing very rapidly. The latest theory that currently carried out by the concept of neuromarketing biometrics, which can influence consumer psychology, so consumers are interested in buying the products, goods, or services offered. Brain imaging techniques are used in biometrics neuromarketing research using fMRI, EEG, eye tracking, and others. The purpose of this research is to find and describe the urgency of using neuromarketing biometrics technology in marketing strategies. Biometric neuromarketing implementation analyzes marketing strategies and also analyze perspective of basic principles of Islamic business ethics towards using technology and biometrics neuromarketing implementation. This research is a type of qualitative research with a library research approach. Data obtained from journals that discuss the use of these technologies, then analyzed using interactive analysis techniques. The results show that neuromarketing biometrics is a useful technology in helping marketers determine marketing strategies because by using this technology, marketers get valuable internal data in the unconscious consumer brain. But in its implementation, there are deviations from the basic principles of Islamic business ethics, including the use of psychological discounts, sense of urgency, and fraud in advertising. While in the use of technology, three things that are highlighted, including the issue of conquering the mind and using it in advertising interests, the problem of violating the free will of consumers, and the problem of violating federal guidelines using human subjects. It hopes that future researchers will be a focus on the study of Islamic business ethics on the use of neuromarketing biometrics technology.
\end{abstract}

Keywords: neuromarketing; Islamic business ethics

\section{Pendahuluan}

Kebutuhan manusia yang bersifat tak terbatas dan keinginannya yang berkembang secara terus menerus membuat kegiatan bisnis semakin lama semakin menjamur di sekitar masyarakat. Baik heterogenitas maupun homogenitas kegiatan-kegiatan bisnis yang ada saat ini, membuat persaingan di antara para pelaku usaha untuk menarik perhatian konsumen semakin tinggi. Persaingan bisnis merupakan aktivitas ekonomi yang penting sebagai acuan untuk meningkatkan kualitas produksi. Persaingan bisnis harus dilakukan secara sportif dan sesuai tuntunan agama. Karena jika kegiatan bisnis merugikan banyak pihak disebabkan ketidakjujuran pelaku usaha, maka bisnis tersebut tidak boleh dijalankan.

Allah swt melarang manusia untuk berlaku curang dan menganjurkan untuk bertransaksi dengan jalan suka sama suka, seperti yang dijelaskan dalam al-Quran: 


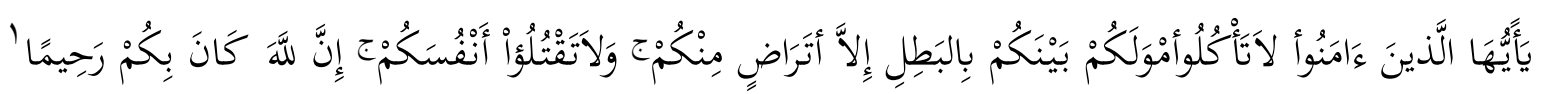

"Hai orang-orang yang beriman, janganlah kamu saling memakan harta sesamamu dengan jalan yang batil, kecuali dengan jalan perniagaan yang berlaku dengan suka sama-suka di antara kamu, dan janganlah kamu membunuh dirimu. Sesungguhnya Allah adalah Maha Penyayang kepadamu."

Di antara strategi usaha yang melayani secara langsung keinginan konsumen adalah strategi pemasaran (marketing). Pemasaran lebih dari sekedar fungsi bisnis yang terisolasi. ${ }^{2}$ Pemasaran merupakan sebuah filosofi yang memandu seluruh organisasi. Departemen pemasaran tidak dapat berdiri sendiri dalam menciptakan nilai pelanggan dan membangun hubungan pelanggan yang menguntungkan. Proses ini memerlukan peran serta seluruh bagian perusahaan yang meliputi keputusan yang luas tentang siapa yang diinginkan perusahaan untuk menjadi pelanggannya, kebutuhan yang harus dipuaskan, produk dan jasa apa yang ditawarkan, penetapan harga, komunikasi yang dikirimkan, dan hubungan kemitraan yang dikembangkan. Bagian pemasaran harus bekerja sama dengan departemen lainnya dalam perusahaan dan dengan organisasi lain untuk memuaskan pelanggan dengan menciptakan nilai unggul bagi pelanggan. ${ }^{3}$

Para pemasar semakin lama semakin menyadari bahwa mengelompokkan konsumen dari segi demografis, seperti penghasilan, umur, sudah tidak memadai lagi. Oleh karena itu, para pemasar mulai mencoba mengadakan pendekatan dari sisi kejiwaan. Maka muncullah pendekatan psikologi dalam pemasaran. Pendekatan psikologi pemasaran selanjutnya berkembang tidak hanya menyangkut masalah segmentasi pasar saja, tetapi juga digunakan dalam seluruh aspek kegiatan pemasaran. Psikologi pemasaran pada hakekatnya adalah integrasi ilmu psikologi dan perilaku manusia ke dalam kegiatan pemasaran untuk mensukseskan tujuan pemasaran, yaitu penjualan yang maksimal. Orang membeli sesuatu adalah untuk memenuhi kebutuhan dan memuaskan keinginannya.

Seiring berjalannya waktu, kegiatan pemasaran (marketing) juga berkembang sangat pesat. Teori mutakhir yang kini tengah diusung adalah konsep biometrika neuromarketing yang faktanya dapat mempengaruhi psikologi konsumen sehingga konsumen tertarik untuk membeli produk, barang atau jasa yang ditawarkan.

Teknik-teknik memanipulasi perilaku konsumen sudah dikembangkan sejak lama. Namun demikian, seiring dengan semakin kompleksnya perilaku konsumen itu sendiri, metode yang ada dinilai masih kurang efisien. Oleh karena itu, konsep neuromarketing yang telah dikembangkan pada awal tahun 2002 diusung di mana keterlibatan ilmu psikologi menjadi sangat dominan. ${ }^{4}$ Premisnya adalah keputusan membeli dibuat oleh konsumen dalam waktu yang sangat singkat pada bagian otak yang menangani emosi yang tidak sepenuhnya disadari. Kemudian, dengan memahami apa yang kita sukai, tidak sukai, inginkan, takutkan, bosankan dan lain-lain seperti yang diindikasikan melalui reaksi otak kita terhadap berbagai stimulus merek, pemasar dapat mendesain produk dan komunikasi yang lebih memenuhi

\footnotetext{
${ }^{1}$ al-Quran, 4: 29.

${ }^{2}$ Philip Kotler dan Garry Amstrong, Prinsip-Prinsip Pemasaran, edisi 12 (Jakarta: Erlangga, 2008), 133.

${ }^{3}$ Ibid., 134.

4 Christoper Morin, "Neuromarketing: The New Sciene of Consumer Behavior", dalam www.researchgate.net/publication/226228201, diakses pada 31 Oktober 2017.
} 
kebutuhan pasar "yang belum terpenuhi”, yang menghubungkan dan menggerakkan "aktivitas membeli".5

Selama beberapa dekade, metode riset pemasaran (marketing) telah bertujuan untuk menjelaskan dan memprediksi efektivitas kampanye iklan. Tetapi, sebagian besar teknik konvensional mengalami kegagalan, karena emosi yang kuat menjadi mediator bagaimana pandangan dan pemahaman konsumen melalui sebuah pesan iklan itu terbentuk. Misalnya, para peneliti telah mengandalkan kemampuan konsumen untuk melaporkan bagaimana pandangan mereka pada suatu iklan. Metode pengambilan data dapat berupa wawancara perorangan yang bersifat rahasia atau tertutup. Sayangnya, metode ini memiliki cukup keterbatasan. Pertama, pemasar menganggap bahwa orang-orang yang benar-benar mampu menjelaskan proses kognitif mereka sendiri sebenarnya memiliki komponen bawah sadar. Kedua, banyak faktor yang dapat memotivasi peserta penelitian untuk mendistorsi pelaporan perasaan mereka, termasuk insentif, kendala waktu, maupun tekanan teman sebaya.

Penelitian Asela A. Burgos Campero dengan judul "Analytical Approach to Neuro Marketing As a Bussines Strategy" mengatakan bahwa dalam proses pengambilan keputusan manusia, termasuk emosi, komponen terbesarnya terjadi secara tak sadar yang diatur oleh sistem limbik di otak. Dia menyebutkan aktivitas otak tak sadar memiliki kekuatan yang besar, cepat, dapat mengatasi perintah atau tugas yang banyak dalam waktu yang bersamaan, juga dilengkapi pola kemampuan pengenalan stimulus yang unik. Sebaliknya aktivitas otak sadar bekerja lebih lambat, hanya bisa fokus pada satu perintah atau tugas dalam satu waktu, dan tidak dapat mengatasi hal-hal yang kompleks. Berdasarkan hal tersebut dapat dikatakan bahwa aktivitas otak tak sadar memiliki andil lebih besar untuk pengambilan keputusan pembelian konsumen.

Permasalahan yang tengah dihadapi para pelaku marketing saat ini adalah mereka tidak tahu apa yang terjadi di bagian otak tak sadar manusia. Aktivitas otak sadar dan tak sadar manusia bekerja secara paralel. Otak sadar manusia tidak tahu apa yang sedang terjadi dalam otak tak sadarnya. Hal tersebut dapat terlihat, karena konsumen tidak tahu secara pasti mangenai perilaku, nilai-nilai, motivasi, kepercayaan, tujuan dan faktor-faktor lainnya yang mempengaruhi perilaku mereka. Salah satu cara paling efektif untuk memperoleh informasi mengenai aktivitas otak tak sadar konsumen adalah dengan menggunakan bantuan peralatan diagnosis medis, dibanding dengan mereka menjelaskannya. Konsumen cenderung tidak memikirkan apa yang mereka rasakan, tidak menyebutkan apa yang betul-betul mereka pikirkan, dan tidak melakukan apa yang mereka katakan sehingga dapat menghasilkan biasbias yang begitu besar dalam riset pasar yang dilakukan secara konvensional.

Isu utama dalam penelitian neuromarketing adalah masalah etika dalam meningkatkan keuntungan komersial. Dalam sudut pandang ilmiah, neuromarketing merupakan suatu keadaan di mana memungkinkan peneliti untuk merancang sebuah kampanye pemasaran sangat adiktif yang mengabaikan kehendak bebas individu. ${ }^{7}$ Bidang neuromarketing ditinjau

\footnotetext{
5 Joel J. Davis, Penelitian Periklanan, Teori dan Praktik, Edisi Kedua (Jakarta: Rajawali Pers, 2013), 318.

6 LCI. Asela A. Burgos Campero dan Jose G. Vargas Hernandes, "Analytical Approach to Neuro Marketing As a Bussines Strategy", Journal of Research in International Business and Management Volume 2, Nomor 12 (December 2012), 1-7.

${ }^{7}$ Madan, C. R. "Neuromarketing: The Next Step in Market Research?", Jurnal Eureka, Volume 1, Nomor 1 (Januari 2010), 34-42.
} 
dengan hati-hati oleh kelompok perlindungan konsumen serta banyak akademisi karena implikasi etis dalam merancang iklan untuk sengaja menyebabkan efek neurologis tertentu. ${ }^{8}$

Teori AIDA (Attention, Interest, Desire, Action), yang selama ini menjadi tujuan beriklan nampaknya tidak berlaku lagi sejak kehadiran neuromarketing. Dengan neuromarketing, seorang pemasar tidak lagi mengharapkan perhatian (attention) dan ketertarikan (interest) seorang konsumen terhadap suatu iklan, tapi langsung menyentuh pada desire atau hasrat seseorang untuk memiliki apa yang ada di dalam iklan tersebut.

Dari beberapa percobaan yang telah dilakukan oleh para ahli Neuroscience dan pemasar ada sebuah ketakutan bahwa ilmu ini akan dipergunakan untuk mengintai pikiran konsumen. Bahkan, sebuah organisasi di Amerika Serikat yang bernama Commercial Allert, mengkhawatirkan praktik neuromarketing merupakan tindakan menaklukkan pikiran dan menggunakannya untuk kepentingan iklan.

\section{Pengertian dan Sejarah Neuromarketing}

Berdasarkan istilahnya, neuromarketing terdiri dari dua kata, yaitu neuro atau neuroscience yang merupakan cabang ilmu pengetahuan yang mempelajari tentang pikiran atau fisiologis otak, dan marketing (pemasaran).

Joel J. Davis berpendapat bahwa neuromarketing atau neuropemasaran adalah label yang diberikan pada penggunaan observasi otak untuk alasan pemasaran. ${ }^{9}$ Lindstorm mengatakan bahwa neuromarketing adalah perpaduan yang menarik antara ilmu pemasaran dan neuroscience yang menggali pikiran bawah sadar, perasaan, dan keinginan terutama dalam proses keputusan konsumen terhadap produk atau layanan. ${ }^{10}$

Christhoper Madan mengatakan bahwa "Neuromarketing is an emerging interdisciplinary field that combines psychology, neuroscience, and economics". ${ }^{11} \mathrm{Jadi}$, tidak hanya ekonomi dan neuroscience saja yang terlibat di dalamnya, neuromarketing juga melibatkan ilmu psikologi dalam penggunaanya. Tujuan dari neuromarketing adalah untuk mempelajari bagaimana otak secara psikologi dipengaruhi oleh iklan dan strategi pemasaran lainnya.

Penelitian Asela A. Burgos-Campero and José G. Vargas-Hernández yang berjudul "Analytical Approach To Neuromarketing as a Business Strategy" mengatakan bahwa neuromarketing mengizinkan kita untuk mengetahui bagaimana reaksi otak kita melihat sebuah produk tanpa harus menjelaskan bagaimana dan apa yang mereka rasakan. ${ }^{12}$ Dengan demikian, seorang marketer bisa merancang strategi bisnis dengan cara mengembangkan produk tersebut, baik itu dari kemasan, iklan, harga maupun variabel pemasaran lainnya.

Penelitian neuromarketing menghilangkan subjektivitas dengan melakukan pengukuran perilaku otak yang dapat diamati. Pemikiran neuromarketing mudah dipahami, yakni premisnya adalah keputusan membeli dibuat oleh konsumen dalam waktu yang sangat singkat

\footnotetext{
8 Ibid.

9 Joel J. Davis, Penelitian Periklanan, 318.

10 M. Lindstrom, Buy-Ology Rahasia di Balik Keputusan Membeli (Jakarta: Elex Media Komputindo, 2011$), 6$.

11 Christoper R. Madan, “Neuromarketing: The Next Step In Market Research?”, Journal of Eureka, Volume 1, Nomor 1 (2010), 34.

12 LCI. Asela A. Burgos Campero dan Jose G. Vargas Hernandes, “Analytical Approach to Neuro Marketing As a Bussines Strategy", Journal of Research in International Business and Management, Volume 2, Nomor 12 (Desember 2012), 1-7.
} 
pada bagian otak yang menangani emosi yang tidak sepenuhnya disadari. Kemudian, dengan memahami apa yang kita sukai, tidak sukai, inginkan, takutkan, bosankan dan lain-lain seperti yang diindikasikan melalui reaksi otak kita terhadap berbagai stimulus merek, pemasar dapat mendesain produk dan komunikasi yang lebih memenuhi kebutuhan pasar "yang belum terpenuhi", yang menghubungkan dan menggerakkan "aktivitas membeli". ${ }^{13}$ Dalam penelitian Harit Kumar dan Priyanka Singh dengan judul "Neuromarketing: An Emerging Tool of Market Research" menyebutkan bahwa kecepatan pengambilan keputusan membeli yang dilakukan oleh otak yang menangani emosi terjadi selama 2,6 detik saja. ${ }^{14}$

Tujuan dari neuromarketing adalah untuk mempelajari bagaimana otak secara fisiologis dipengaruhi oleh iklan dan strategi pemasaran. ${ }^{15}$ Neuromarketing penting dipelajari, karena neuromarketing dapat menemukan proses implisit dan otomatis yang dapat membuat proses pengambilan keputusan, dan dapat mengungkapkan informasi tentang perilaku konsumen yang tidak dapat diperoleh dari metode pemasaran konvensional. ${ }^{16}$ Hal ini dapat membuat segmentasi pelanggan lebih efektif dilakukan, yang akhirnya akan mengarah pada peningkatan pemasaran produk dan peningkatan volume penjualan.

Dua teknik utama pengukuran pola dan keaktifan gelombang otak dalam neuromarketing adalah $f$ MRI dan EEG. ${ }^{17} f$ MRI dapat mengidentifikasi area spesifik otak yang aktif pada waktu yang spesifik, dengan cara mengukur perubahan aliran darah dan suplai oksigen oksigen dalam otak. Area otak yang aktif akan lebih membutuhkan banyak oksigen untuk bereaksi. Sedangkan EEG mengukur dan mencatat aktivitas aliran listrik dalam otak, yang hasilnya memberikan wawasan tentang tingkat keaktifan otak, tetapi tidak dapat menjelaskan area spesifik otak yang aktif.

\section{The Pepsi Paradox; Salah Satu Penerapan Biometrika Neuromarketing}

Contoh penggunaan teknologi neuromarketing yang paling familiar adalah kasus "The Pepsi Paradox"18 yang melibatkan minuman bersoda Coca-cola. Penelitian ini melibatkan responden sebanyak 67 individu. Pada awalnya, dilakukan "blind taste test". Responden tidak diberitahukan merek minuman bersoda apa yang mereka minum. Hasilnya, semua responden menunjukkan level keaktifan yang kuat dan hampir sama pada area otak yang menangani kepuasan. Tetapi, ketika percobaan kedua dilakukan dan responden diberitahukan merek minuman apa yang mereka minum, tiga dari empat responden lebih "memilih" Coca-cola dengan area otak yang aktif adalah bagian ingatan yang kuat dan menyenangkan. Jadi, dapat disimpulkan bahwa iklan Coca-cola mendapat tempat yang baik dari pada Pepsi dan itu membuat marketing di perusahaan Pepsi untuk membuat iklan ataupun tampilan Pepsi lebih disukai oleh konsumen.

\footnotetext{
13 Joel J. Davis, Penelitian Periklanan, 318.

${ }^{14}$ Harit Kumar dan Priyanka Singh, "Neuromarketing: An Emerging Tool of Market Research", International Journal of Engineering and Management Research, Volume 5, Nomor 6 (December 2015), 530-535.

15 Joel J. Davis, Penelitian Periklanan, 304.

16 Venkatraman, V. et al, "New Scanner Data for Brand Marketers: How Neuroscience Can Help Better Understand Differences in Brand Preferences", Journal of Consumer Psychology, Volume 22, Nomor 1 (2012), 143-153.

17 Ibid., 320.

${ }^{18}$ S. M. McClure et al, "Neural Correlates of Behavioral Preference for Culturally Familiar Drinks", Neuron, Volume 44, Nomor 2 (2004), 379-387.
} 
Gambar 1.1. ${ }^{19}$ Scanning Otak pada fMRI dalam Eksperiman Pepsi vs Coke

\section{Branding and memory}

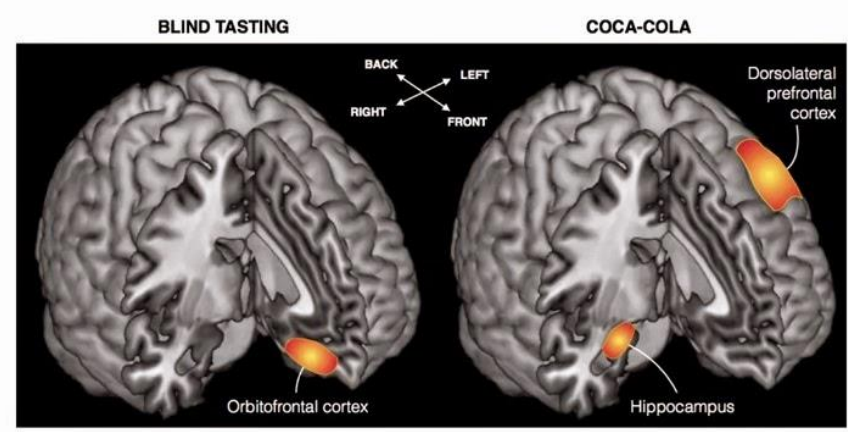

\section{Prinsip Dasar Etika Bisnis Islam}

Aplikasi etika bisnis Islam pada dasarnya mengacu pada prinsip dasar etika bisnis Islam, di antaranya adalah sebagai berikut:

1. Prinsip unity (kesatuan)

Merupakan refleksi konsep tauhid yang memadukan seluruh aspek kehidupan baik ekonomi, sosial, politik budaya menjadi keseluruhan yang homogen, konsisten dan teratur. Adanya dimensi vertikal (manusia dengan penciptanya) dan horizontal (sesama manusia). Prakteknya dalam bisnis:

a. Tidak ada diskriminasi baik terhadap pekerja, penjual, pembeli, serta mitra kerja lainnya.

b. Meninggalkan perbuatan yang tidak beretika dan mendorong setiap individu untuk bersikap amanah karena kekayaan yang ada merupakan amanah Allah.

2. Prinsip equilibrium (keseimbangan)

Berkaitan dengan konsep adil. Merupakan suasana keseimbangan di antara berbagai aspek kehidupan manusia (sosial, politik, ekonomi, agama, dan lain-lain), yang membentuk tatanan sosial yang harmonis. Keseimbangan, kebersamaan, dan kemoderatan merupakan prinsip etis yang harus diterapkan dalam aktivitas maupun entitas bisnis.

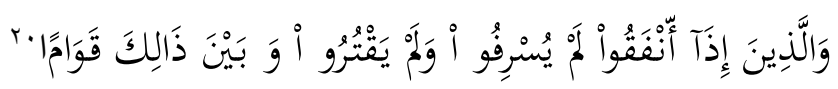

"Dan orang-orang yang apabila membelanjakan (harta), mereka tidak berlebihan, dan tidak (pula) kikir, dan adalah (pembelanjaan itu) di tengah-tengah antara yang demikian".

3. Prinsip free will (kehendak bebas)

Kebebasan merupakan bagian penting dalam nilai etika bisnis Islam, tetapi kebebasan itu tidak merugikan kepentingan kolektif. Kepentingan individu dibuka lebar. Tidak adanya batasan pendapatan bagi seseorang mendorong manusia untuk aktif

19 Samuel Mc.Clure, "The Pioneer of Neuromarketing”, dalam http://passioncomm.com/articles/in-a-battle-tothe-death-emotional-marketing-wins/, diakses pada 13 Juli 2019.

${ }^{20}$ al-Quran, 18: 67. 
berkarya dan bekerja dengan segala potensi yang dimilikinya. Sampai pada tingkat tertentu, manusia dianugerahi kehendak bebas untuk memberi arahan dan membimbing kehidupannya sendiri sebagai khalifah di muka bumi.

Berdasarkan prinsip kehendak bebas ini, manusia mempunyai kebebasan untuk membuat suatu perjanjian termasuk menepati janji atau mengingkarinya. Tentu saja seorang muslim yang percaya kepada kehendak Allah akan memuliakan semua janji yang dibuatnya.

Kebebasan merupakan bagian penting dalam nilai etika bisnis Islam. Kebebasan bagi individu dibuka lebar, tetapi kebebasan itu tidak merugikan kepentingan kolektif. Tidak ada pula batasan pendapatan bagi seseorang untuk aktif bekerja dan berkarya dengan segala potensi yang dimilikinya. Dalam ekonomi Islam, kebebasan ialah tetap menggabungkan antra nilainilai moral dan spiritual. Karena apabila tidak ada filter moral, maka kegiatan ekonomi akan rawan kepada perilaku destruktif yang dapat merugikan masyarakat luas. Telah terjadi tradisi di masyarakat sekarang ini bahwa dalam kegiatan ekonominya cenderung mengedepankan materialisme tanpa memperdulikan moralitas.

Seharusnya kebebasan manusia yang ada adalah kebebasan yang bertanggung jawab, yaitu kebebasan yang didasari oleh 'ilm (ilmu) dan kesadaran penuh. Manusia bebas bertindak, yaitu manusia bebas berbuat sesuatu dengan tujuan dan disengaja yang dipengaruhi faktor internal dan eksternal dirinya. Bisa jadi hal itu disebabkan oleh pengaruh ajaran, agama, bacaan, lingkungan dan lain sebagainya. Kebebasan dengan kewajiban moral yaitu bahwa seseorang yang melakukan sesuatu kewajiban karena ia setuju, walau itu membutuhkan pengorbanan, karena didapati tindakan tersebut ternyata dapat membuat ia merasa bebas. Kebebasan bertanggung jawab yaitu sesungguhnya sikap moral yang mature atau dewasa adalah sikap yang bertangung jawab dan tidak mungkin ada tanggung jawab tanpa ada kebebasan.

4. Prinsip responsibility (tanggung jawab)

Secara logis prinsip ini berhubungan erat dengan prinisp kehendak bebas. Ia menetapkan batasan mengenai apa yang bebas dilakukan oleh manusia dengan bertanggung jawab atas semua yang dilakukannya. Kebebasan yang tak terbatas adalah sebuah absurditas, ia mengimplikasikan tidak adanya sikap tanggung jawab. Untuk memenuhi konsep keadilan dan kesatuan seperti yang kita lihat dalam ciptaan Allah, manusia harus bertanggung jawab terhadap segalan tindakan yang dilakukan.

5. Prinsip benevolence (kebenaran)

Kebenaran di sini juga meliputi kebajikan dan kejujuran. Maksud dari kebenaran adalah niat, sikap dan perilaku benar dalam melakukan berbagai proses baik itu proses transaksi, proses memperoleh komoditas, proses pengembangan produk maupun proses perolehan keuntungan.

Kebajikan artinya melaksanakan perbuatan baik yang dapat memberikan kemanfaatan kepada orang lain, tanpa adanya kewajiban tertentu yang mengharuskan perbuatan tersebut atau dengan kata lain beribadah dan berbuat baik seakan melihat Allah, jika tidak mampu maka yakinlah bahwa Allah melihat. Dalam al-Quran prinsip kebenaran yang mengandung kebajikan dan kejujuran dapat diambil dari penegasan keharusan menunaikan atau memenuhi perjanjian atau transaksi bisnis. 


\section{Neuromarketing dalam Etika Bisnis Islam}

Neuromarketing adalah sebuah perkawinan menarik antara ilmu pemasaran dan neuroscience yang menggali pikiran bawah sadar, perasaan, dan keinginan terutama dalam proses pengambilan keputusan konsumen terhadap produk atau layanan. ${ }^{21}$

Secara fungsinya, otak kita dibagi menjadi dua bagian, yaitu bagian yang menangani rasional dan bagian yang menangani emosional. Berdasarkan penelitian dalam bidang neuroscience, diketahui bagian otak yang menangani masalah emosional disebut limbic $^{22}$ mempunyai andil yang lebih besar dalam proses pengambilan keputusan konsumen, dari pada otak yang menangani rasional. Karena emosi adalah cara kerja otak kita dalam menerjemahkan nilai-nilai dan merek. Ritty Francis dalam penelitiannya bahkan mengatakan "It's estimated that 95 percent of all thought occurs in our subconscious minds-which traditional research methods can't measure". 23 Yang berarti bahwa 95\% pengambilan keputusan membeli konsumen dilakukan oleh bagian otak yang menangani emosional.

\section{Gambar 1.2. Sistem Otak Manusia ${ }^{24}$}

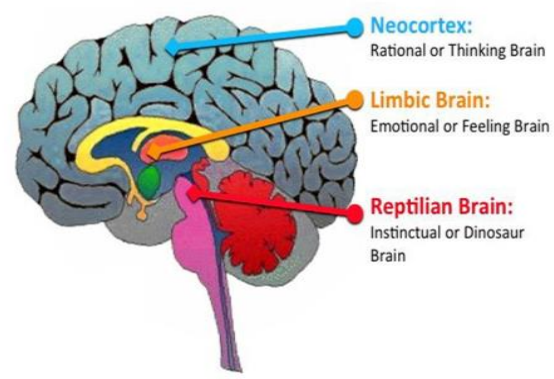

Isu utama dalam penelitian neuromarketing adalah masalah etika dalam meningkatkan keuntungan komersial. Dalam sudut pandang ilmiah, neuromarketing merupakan suatu keadaan di mana memungkinkan peneliti untuk merancang sebuah kampanye pemasaran sangat adiktif, yang mengabaikan kehendak bebas individu. ${ }^{25}$ Bidang neuromarketing ditinjau dengan hati-hati oleh kelompok perlindungan konsumen serta banyak akademisi karena implikasi etis dalam merancang iklan untuk sengaja menyebabkan efek neurologis tertentu. ${ }^{26}$

Tampak jelas bahwa neuromarketing secara mutakhir menginformasikan pengambilan keputusan periklanan dan berpotensi menyediakan wawasan yang bahkan lebih banyak lagi pada masa mendatang. Meskipun demikian, banyak keprihatinan yang muncul dari pendekatan ini. Keprihatiann tersebut muncul dari isu penggunaan teknik pencitraan otak

\footnotetext{
${ }^{21}$ M. Lindstrom, Buy-Ology Rahasia di Balik Keputusan Membeli (Jakarta: Elex Media Komputindo, 2011), 22 23.

${ }^{22}$ Sistem limbic adalah himpunan struktur otak yang terletak pada kedua sisi talamus, tepat di bawah serebrum. Sistem limbik juga mengacu pada korteks paleomamalia. Sistem limbic mendukung berbagai fungsi, seperti emosi, perilaku, motivasi, memori jangka panjang, dan penciuman.

${ }^{23}$ Ritty Francis dan Reena R, “A Study on Neuromarketing: A Unique Bond between Consumer's Cognizance and Marketing", International Journal of Commerce and Management Research, Volume 2, Nomor 11 (November 2016), 54.

${ }^{24}$ Bram Ardianto, “Otak Reptile, Sistem Limbik dan Neokorteks", dalam https://bramardianto.com/otak-reptilsistem-limbik-dan-neokorteks.html, diakses pada 13 Juli 2019.

${ }^{25}$ Madan, C. R. "Neuromarketing: The Next Step in Market Research?”, Jurnal Eureka, Volume 1, Nomor 1 (Januari, 2010), 34-42.

26 Ibid.
} 
pada pengambilan keputusan periklanan. Wilson dan para koleganya merangkum ketidaksetujuan etis tersebut.

"Pendapat kami adalah bahwa berbagai temuan dan metode neuroscience mengandung potensi praktik pemasaran yang mengancam kemampuan konsumen untuk mengikuti preferensi dan determinasi konsumen yang berkehendak bebas. Konteks ini menunjukkan bahwa berbagai batasan eksternal pengambilan keputusan yang tertanam melalui aplikasi manipulasi saraf merupakan kemungkinan pelanggaran. Pelanggaran sangat problematik ketika manipulasi terjadi tanpa pengetahuan, persetujuan dan pemahaman eksplisit." 27

Lowry berpandangan lebih ekstrim lagi, bahwa fokus pada neuromarketing ini mengalihkan pada tujuan awal mereka, yakni beriklan, pada tujuan yang diyakini adalah tujuan sesungguhnya mereka menciptakan iklan yang membedakan mereknya dan menargetkan perasaan konsumen.

"Saya mendapati bahwa praktik neuromarketing tidak sopan dan bertentangan dengan segala prinsip pengalaman konsumen. Ketimbang mengacaukan pikiran mereka, berfokuslah pada perasaannya, mengembangkan pengalaman yang menarik dan secara finansial dapat dibenarkan. Pelanggan sekarang jauh lebih cerdas dan berdaya dibandingkan dengan dulu. Sudah waktunya untuk berhenti menghina mereka. Dalam sebuah hubungan resiprokal, perlakukanlah mereka sebagai mitra yang jujur. Perlakukanlah mereka sebagai individu, bukan mesin, dan doronglah kemampuan mereka untuk mengambil keputusan. Jika anda ingin mengambil keputusan yang tepat, berikanlah kepada mereka alasan yang tepat, bukan sebuah hasil pemindaian otak."28

Dari beberapa percobaan yang telah dilakukan oleh para ahli Neuroscience dan pemasar, ada sebuah ketakutan bahwa ilmu ini akan dipergunakan untuk mengintai pikiran konsumen. Bahkan, sebuah organisasi di Amerika Serikat yang bernama Commercial Allert, mengkhawatirkan praktik neuromarketing merupakan tindakan menaklukkan pikiran dan menggunakannya untuk kepentingan iklan. ${ }^{29}$ Mereka juga mengatakan bahwa kegiatan neuromarketing tidak etis dilakukan karena pelaku neuromarketing dapat menembus privasi dari konsumen dengan menggunakan alat kesehatan, yang dapat menyebabkan neurocapitalism. Selain itu, mereka juga mengatakan bahwa kegiatan neuromarketing melanggar pedoman federal untuk penelitian dengan subjek manusia.

Adapun analisis etika bisnis Islam terkait beberapa isu dalam penggunaan teknologi biometrika neuromarketing antara lain adalah sebagai berikut:

1. Isu menaklukkan pikiran dan menggunakannya untuk kepentingan iklan

Teknologi biometrika neuromarketing memungkinkan pemasar untuk mengetahui apa yang ada di dalam otak konsumen, bahkan tanpa disadari oleh konsumen itu sendiri. Hal ini diakibatkan karena yang diteliti dan diambil data adalah bagian otak tak sadarnya.

\footnotetext{
${ }^{27}$ R. Mark Wilson, et al, "Neuromarketing and Consumer Fre Will", The Journal of Consumer Affairs, Volume 42, Nomor 1 (Maret 2008), 389.

${ }^{28}$ Lior Arrusy, “Neuromarketing Isn’t Marketing”, Costumer Relationship Management (Januari 2009), 12.

${ }^{29}$ Commercial Alert, "Commercial Alert Asks Emory University to Halt Neuromarketing Experiments", dalam http://www.commercialalert.org/PDFs/neuromarketin grel. pdf, diakses pada 15 Mei 2019.
} 
Tindakan tersebut pada dasarnya merupakan tindakan yang tidak etis karena dengan berbekal data internal dari dalam otak konsumen, pemasar bisa saja merancang iklan yang tanpa disadari konsumen membuat konsumen merasa kecanduan. Apabila seorang pemasar telah menemukan dan menyentuh "buy botton"30 dari konsumen, maka konsumen tidak akan menolak apa yang ditawarkan iklan tersebut.

Dalam memahami konsumen untuk membangun sebuah komunikasi periklanan, maka seorang pemasar harus dapat menangkap gelombang pemancar dari konsumen tersebut. Gelombang tersebut berupa insight atau pikiran terdalam, yang tidak sepenuhnya disadari oleh konsumen, yang tidak terlihat namun sebenarnya bisa dirasakan.

Tujuan beriklan yang sebelumnya dirancang secara sistematis dalam teori AIDA (Attention, Interest, Desire, Action) sepertinya tak berlaku sejak munculnya neuromarketing. Dengan menggunakan teknologi neuromarketing, seorang pemasar dapat merancang sebuah iklan dan bauran pemasaran seperti yang "dikehendaki" oleh konsumen. Pemasar dapat langsung menyentuh hasrat (desire) konsumen untuk membeli produknya tanpa harus kesulitan memikirkan bagaimana menarik perhatian (attention) konsumen dari produk yang ditawarkannya. Desain memberikan peran yang penting dalam proses percepatan ini, yaitu menghadirkan percepatan dalam pemahaman terhadap sebuah pesan dalam bentuk visual, sehingga dapat menghadirkan kesan yang sangat emosional.

Dengan demikian, secara tidak langsung terdapat indikasi "pemaksaan" dalam proses keputusan membeli. Jika tujuan dari penggunaan teknologi biometrika neuromarketing adalah untuk meracuni pikiran konsumen dalam pembuatan iklan yang adiktif, maka hal tersebut tidak sejalan dengan prinsip-prinsip Islam dalam berbisnis yang salah satunya tersurat dalam hadis riwayat Ibnu Majah:

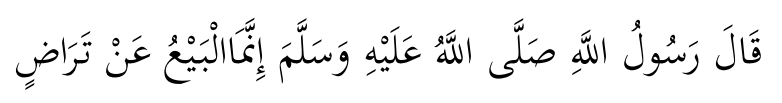

"Nabi bersabda: Sesungguhnya jual beli itu hanya sah jika berdasar suka sama suka."

Berdasarkan hal tersebut, maka banyak peneliti dalam bidang neuromarketing yang menginginkan adanya menyarankan penciptaan kode etik yang akan diadopsi oleh industri neuromarketing. Tujuan keseluruhan dari kode etik tersebut adalah untuk mendorong penelitian dan pengembangan, kewirausahaan dan profitabilitas perusahaan dengan menerapkan teknologi neuromarketing dengan cara yang bermanfaat dan tidak berbahaya dalam semua tahap pengembangan, implementasi dan penyebaran. Kode tersebut harus, antara lain mengatasi masalah yang berkaitan dengan keselamatan responden (kesehatan, efek pemindaian, penanganan gambar), serta perlindungan yang terancam oleh eksploitasi pemasaran.

Terlepas dari kontroversi penggunaan teknologi biometrik neuromarketing yang seakan-akan memaksa konsumen untuk membeli produk yang ditawarkan, ternyata

${ }^{30}$ Buy Botton adalah salah satu area otak yang bertanggung jawab terhadap keputusan pembelian. Area ini dapat ditemukan apabila otak dieksplor secara terus menerus. 
penggunaan teknologi ini efektif untuk "kampanye pemasaran". Misalkan, selama bertahun-tahun, penggunaan slogan peringatan "merokok membunuhmu" disertai dengan gambar penyakit yang diakibatkan rokok, diharapkan efektif untuk membuat seseorang berhenti merokok karena adanya peringatan ini dalam iklan maupun setiap bungkus rokok. Tetapi, dengan neuromarketing penggunaan anggaran yang besar untuk membuat iklan dan kampanye pemasaran anti merokok sadar bahwa penggunaan slogan disertai gambar tersebut hanyalah sia-sia. Hasil penelitian menyebutkan bahwa ketika seorang perokok aktif diperlihatkan desain kemasan rokok dengan tulisan "merokok membunuhmu" atau yang sejenisnya disertai gambar, ternyata malah membuat area otak yang menangani "kenangan indah" diaktifkan. Ini berarti bahwa kampanye anti merokok dalam kemasan maupun iklan sangat tidak efektif untuk menghentikan seorang perokok untuk tidak merokok lagi.

Penggunaan teknologi biometrika neuromarketing di bidang kampanye anti merokok ini terdapat nilai-nilai kebaikan di dalammya, sesuai dengan prinsip etika bisnis Islam. Karena dengan adanya temuan ini, biaya untuk kampanye anti merokok dapat ditekan dan dapat dicari metode yang lebih efektif dalam penggunaan biaya kampanye anti merokok ini.

2. Isu melanggar kehendak bebas konsumen (free will)

Teori perilaku konsumen menyebutkan ada beberapa faktor yang mendasari seorang konsumen dalam membuat keputusan membeli. Konsumen berhak mendapatkan produk dan jasa dengan kualitas yang sesuai dengan harga yang mereka bayar. Tetapi, dengan adanya neuromarketing, seolah-olah konsumen hanya dibatasi oleh beberapa pilihan produk.

Seperti dijelaskan di atas, bahwa dalam penelitian biometrika neuromarketing mampu mengumpulkan data internal dari konsumen dengan objektif. Terutama di era digital marketing saat ini, privasi informasi tentang preferensi konsumen menjadi hal yang sangat berharga bagi perusahaan. Melalui neuromarketing, informasi tersebut dapat didapatkan. Seperti alamat email, riwayat pembelian, riwayat pencarian, dan lain sebagainya. Dan informasi tersebut bisa diperjua-belikan oleh perusahaan-perusahaan yang menginginkannya. Dengan berbekal data tersebut, perusahaan dapat dengan mudah berinteraksi dengan konsumen secara bebas dengan menawarkan produk maupun jasa yang mereka jual. Neuromarketing menyediakan kemungkinan mendeteksi data tentang pengambilan keputusan pembelian dan preferensi pembeli yang belum diketahui sampai sekarang. Untuk mengubah data menjadi informasi, neuromarketing harus "belajar" bagaimana menghubungkan data yang dikumpulkan dengan preferensi, seleksi dan perilaku konsumen, untuk mencapai tujuan yang ditetapkan, yang tentunya merupakan salah satu area penelitian neuromarketing di masa depan.

Dalam membuat keputusan pemasaran, terutama periklanan, neuromarketing bisa merongrong otonomi dan kebebasan manusia. Artinya, iklan membuat manusia tidak lagi dihargai kebebasannya dalam menentukan pilihannya untuk memperoleh produk tertentu. Banyak pilihan dan pola konsumsi manusia modern sesungguhnya adalah pilihan iklan. Manusia didekte oleh iklan dan tunduk kepada kemauan iklan, khususnya iklan manipulatif dan persuasif non rasional. 
Salah satu prinsip dasar etika bisnis Islam adalah adanya landasan kehendak bebas (free will) yakni potensi untuk menentukan pilihan yang beragam. Kebebasan manusia tidak dibatasi, maka manusia memiliki kebebasan pula untuk menentukan pilihan yang salah ataupun yang benar. Oleh karena itu kebebasan manusia untuk melakukan kegiatan ekonomi haruslah dilakukan dengan cara-cara yang benar, adil, dan mendatangkan manfaat bagi masyarakat luas menurut al-Quran dan Sunah Rasul.

Selain itu, dalam transaksi jual beli, seorang penjual maupun pembeli memiliki hak yang sama untuk meneruskan atau membatalkan proses jual beli tersebut, berdasarkan Hadis dari Hakim ibn Hizam bahwa Rasulullah bersabda "penjual dan pembeli masih boleh memilih (untuk meneruskan transaksi atau membatalkannya) selama mereka belum berpisah. Jika keduanya jujur dan menjelaskan apa adanya, maka keduanya diberkahi dalam jual belinya. Jika keduanya menyembunyikan (cacat) dan berdusta, maka akan dihapuslah berkah pada keduanya". ${ }^{31}$

3. Isu pelanggaran pedoman federal untuk penelitian dengan subjek manusia

Menurut Milton, ada empat aspek utama yang perlu dipahami oleh seorang peneliti, yaitu: ${ }^{32}$

a. Respect for human dignity (menghormati harkat dan martabat manusia).

b. Respect for privacy and confidentiality (menghormati privasi dan kerahasiaan subyek penelitian).

c. Respect for justice and inclusiveness (keadilan dan inklusivitas).

d. Balancing harms and benefits (memperhitungkan manfaat dan kerugian yang ditimbulkan).

Berbicara mengenai manusia sebagai subyek penelitian, setidaknya ada dua hal yang harus diperhatikan seorang peneliti dalam hal ini adalah neuromarketer (peneliti neuromarketing), yakni:

1. Perlindungan partisipan

Dalam melakukan penelitian, seorang peneliti harus bisa melindungi partisipan dari aspek material, fisik dan psikologi. Artinya, seorang peneliti harus menjamin partisipannya merasa aman, nyaman, sadar, dan tidak mengalami kerugian psikologis seperti trauma.

Data neuroimaging jauh lebih kompleks daripada data perilaku umum atau informasi yang diperoleh dari kuesioner karena otak itu sendiri secara alami sangat kompleks. Selain itu, semua subjek harus mengendalikan gerakan tubuh mereka; subjek diharuskan untuk diam, bahkan dilarang mnggerakkan kepala karena mempengaruhi kualitas pemindaian gambar, oleh karena itu subjek harus diam selama setidaknya 45 menit hingga satu setengah jam tergantung pada kompleksitas penelitian. Hal tersebut mungkin membuat partisipan menjadi kurang nyaman.

2. Informed cosent

Yakni kesediaan seorang partisipan untuk menjadi subjek penelitian yang disadari. Etika penelitian mensyaratkan adanya kesediaan subjek penelitian untuk diteliti. Subjek peneliti memiliki hak untuk menolak dilakukan riset padanya atas berbagai hal. Etika

${ }^{31}$ HR. Bukhari No. 1973 dan Muslim No. 1532.

${ }^{32}$ Milton, C.L, Ethical Issues from Nursing Theoretical Perspectives, 22. 
penelitian mengatakan bahwa subjek peneliti akan memberikan informasi secara sadar tentang apa yang diketahuinya untuk mendukung penelitian yang sedang berlangsung.

Tetapi, dalam penggunaan teknologi biometrika neuromarketing yang menggunakan manusia sebagai subyek penelitian, terutama dengan teknik $f M R I$, peneliti mengambil data dan informasi internal yang bahkan subjek penelitipun tidak menyadarinya. Karena dalam penelitian biometrika, data yang diambil berasal dari otak tak sadar.

Hal tersebut sebenarnya tidak menjadi masalah ketika responden menyatakan bersedia untuk diteliti. Karena sebelum melakukan penelitian neuromarketing, ada banyak tahap yang harus dilalui oleh seseorang untuk menjadi subjek penelitian. Di antaranya adalah pernyataan kesediaan untuk diteliti, melakukan observasi kesehatan dengan dokter untuk memastikan tubuhnya cukup sehat untuk dilakukan penelitian dan lain sebagainya.

\section{Analisis Prinsip Dasar Etika Bisnis Islam terhadap Implementasi Neuromarketing (Neuromarketing Terapan)}

Penggunaan teknologi biometrika neuromarketing sangat berpengaruh terhadap keputusan pembuatan alat pemasaran, yang pada akhirnya akan meningkatkan volume penjualan suatu produk. Berikut akan disampaikan analisis etika bisnis Islam terkait implementasi neuromarketing dalam strategi pemasaran atau biasa disebut neuromarketing terapan.

\section{Analisis Prinsip Dasar Etika Bisnis Islam terhadap Implementasi Neuromarketing pada Promosi (Iklan)}

Iklan adalah salah satu bentuk promosi yang sering digunakan untuk menarik minat pembeli. Sebagaimana diketahui bahwa pada zaman sekarang, untuk mempromosikan komoditi dagangan, seseorang banyak menggunakan sarana iklan yang memikat, baik yang disampaikan dalam bentuk tulisan, lisan, maupun gambar. Tidaklah mengherankan jika dijumpai banyak konsumen yang dikelabui dengan model iklan atau promosi barang lainnya, lantaran promosi tersebut hanya bohong semata dan tidak terbukti dalam realita.

Pemasar harus mampu menunjukkan bahwa mereka jujur, berniat menepati janji, memiliki janji yang realistis dan menawarkan produk yang sesuai syariah. Islam tidak mentolerir perilaku promosi menipu, pernyataan palsu, tidak berdasar, tuduhan dan kesaksian palsu.

Dengan memanfaatkan alat neuromarketing, mereka menemukan bahwa iklan yang lebih menarik mengaktifkan bagian otak yang bernama korteks prefrontal ventromedial dan ventral striatum yang bertanggung jawab untuk emosi dalam proses pengambilan keputusan dan kognisi penghargaan. Wilayah otak ini tidak diaktifkan ketika iklan yang disajikan kurang menarik. Ini menunjukkan bahwa dengan memanfaatkan teknik neuromarketing dimungkinkan untuk mengetahui apakah suatu iklan dianggap menarik atau tidak. Seharusnya, pembuatan iklan untuk menarik minat pembeli harus dilakukan dengan jujur. Tidak melebih-lebihkan produk yang ditawarkan. 
Iklan juga tidak boleh mengandung faktor sense of urgency. Dalam berbagai penelitian yang dilakukan oleh Lindstorm, berkesimpulan bahwa penghargaan dan hukuman adalah perasaan yang paling menekan pikiran manusia, hal ini sering dimanfaatkan oleh iklan dalam menyampaikan pesan persuasi produk. ${ }^{33}$ Misalnya, ketakutan seorang ibu apabila anaknya akan tumbuh pendek jika tidak mengonsumsi merek susu tertentu, iklan properti yang berbunyi "hari Senin harga naik", dan lain sebagainya.

Sense of urgency menciptakan perasaan tidak sempurna (imperfection) atau perasaan kurang (lack) pada setiap diri individu, sehingga mendorong mereka untuk mengkonsumsi produk yang sebenarnya tidak terlalu dibutuhkan. Hal-hal semacam ini akan mengakibatkan perilaku konsumtif bagi konsumen.

Yusuf al-Qardhawi memaparkan beberapa hal yang perlu diperhatikan dalam iklan, di antaranya adalah: ${ }^{34}$

1. Iklan tidak boleh menyampaikan informasi yang palsu dengan maksud untuk memperdaya konsumen.

2. Iklan wajib menyampaikan semua informasi tentang produk tertentu, khususnya menyangkut keamanan dan keselamatan manusia.

3. Iklan tidak boleh mengarah pada pemaksaan, khususnya secara kasar dan terangterangan.

4. Iklan tidak boleh mengarah pada tindakan yang bertentangan dengan moralitas, semisal tindak kekerasan, penipuan, pelecehan seksual, diskriminasi, perendahan martabat manusia dan sebagainya.

\section{Analisis Prinsip Dasar Etika Bisnis Islam terhadap Implementasi Neuromarketing pada} Harga

Instrumen terpenting dalam jual beli adalah harga. Sehingga harga menjadi tolak ukur keadilan dalam jual beli. Allah menetapkan bahwa setiap orang berhak menjual produknya dengan harga yang disukainya. Namun, terdapat rukun dan syarat yang harus dipatuhi dalam hal penentuan harga pada jual beli agar transaksi bernilai. Harga yang adil adalah dambaan bagi penjual maupun pembeli. Harga yang adil tersebut terbentuk atas kekuatan demand and supply antara pembeli dan penjual tanpa adanya paksaan dari pihak manapun. Bahkan Rasulullah sendiripun tidak berani dalam menetapkan harga.

Harga harus mencerminkan manfaat yang di dapatkan oleh penjual dan pembeli secara adil. Maksudnya, pembeli harus memperoleh manfaat yang setara dengan harga yang dibayarkannya dan penjual harus mendapatkan keuntungan yang normal atas apa yang telah dijualnya:

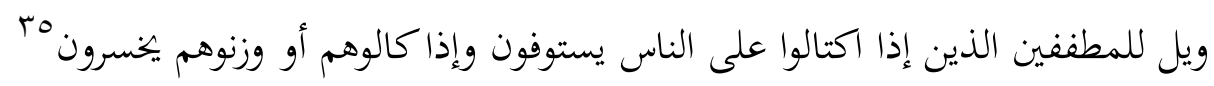

"Kecelakaan besarlah bagi orang-orang yang curang. (Yaitu) orang-orang yang apabila menerima takaran dari orang lain mereka minta dipenuhi. Dan apabila mereka menakar atau menimbang untuk orang lain, mereka mengurangi."

${ }^{33}$ M. Lindstrom, Buy-Ology Rahasia di Balik Keputusan Membeli, 142.

34 Yusuf al-Qaradhawi, Norma dan Etika Ekonomi Islam (Jakarta: Gema Insani Press, 1997), 157.

35 al-Quran, 83: 1-3 
Yang dimaksud dengan orang-orang yang curang di sini ialah orang-orang yang curang dalam menakar dan menimbang. Pelanggaran terhadap harga pasar, misalnya penetapan harga dengan cara dan karena alasan yang tidak tepat, merupakan suatu ketidakadilan yang akan dituntut pertanggungjawabannya di hadapan Allah. Sebaliknya, dinyatakan bahwa penjual yang menjual dagangannya dengan harga pasar adalah laksana orang yang berjuang di jalan Allah, sementara yang menetapkan sendiri termasuk sebuah perbuatan ingkar kepada Allah. ${ }^{36}$

Tujuan neuromarketing adalah untuk mengetahui bagaimana otak secara psikologis dipengaruhi oleh alat pemasaran. Dalam hal penggunaan teknologi neuromarketing pada harga, pemasar dapat memperoleh data informasi internal yang akurat terhadap persepsi konsumen atas harga yang diinginkan. Perlu diingat bahwa neuromarketing bukanlah proses instan, ketika melihat produk dengan harga tertentu langsung dibeli. Tetapi teknologi neuromarketing merupakan langkah dasar untuk menetapkan strategi-strategi bisnis berikutnya. Salah satu strategi penetapan harga adalah penggunaan sistem diskon. Diskon merupakan kata yang sering didengar pada waktu-waktu tertentu. Misalnya ketika menjelang hari raya, tahun baru dan lain sebagainya. Penelitian membuktikan bahwa bagian otak yang menangani rasa kebahagiaan akan aktif jika mendengar kata diskon.

Ada hipotesa yang mengatakan bahwa penjual telah menaikkan harga pasar sebesar nilai yang telah didiskon itu terlebih dahulu, baru kemudian mematok diskon. Konsep seperti itu disebut diskon psikologikal. Ada juga fakta yang mengatakan bahwa pembeli lebih senang mengunjungi stand penjualan dengan tulisan "Sale 15.000,- dapat 3" daripada barang yang ditulis dengan "harga Rp. 5000,-". Padahal ternyata produk yang harganya 15.000,- dapat 3 itu tidak lebih berkualitas daripada produk yang harganya Rp. 5000,-/ pcs.

Rasulullah telah melarang berbagai transaksi yang terjadi dalam ketidaksempurnaan informasi, misalnya menghalangi transaksi pada harga pasar (talaqqi rukbān), mengambil keuntungan tinggi dengan memanfaatkan psikologi konsumen (ghabn fakhish). Berdasarkan hadis riwayat Muslim:

"Dari Abi Hurairah, bahwa Rasulullah pernah melalui satu timbunan dari (biji-biji) makanan, lalu ia masukkan padanya tangannya lalu tangannya kena basah, sabdanya: “Apa ini, hai penjual makanan?” Ia jawab: "Kena hujan ya Rasulullah.” Ia bersabda: "Mengapa engkau tidak taruh dia di sebelah atas supaya orang-orang lihat dia? Barangsiapa menipu, bukanlah ia dari (golongan) kita.” (HR. Muslim).

\section{Analisis Prinsip Dasar Etika Bisnis Islam terhadap Implementasi Neuromarketing pada Pengembangan Produk Baru}

Studi Calvert dan Brammer dengan judul "Predicting Consumer Behavior: Using Novel Mind-Reading Approaches" 37 menghasilkan fakta bahwa fMRI dapat menyaring informasi secara efektif. Oleh karena metode ini dapat diterapkan dalam proses pretest dan pengembangan produk baru, maka akan mengungkapkan informasi internal yang membuat pemasar dapat menentukan pengembangan produk baru mereka. Implementasinya,

\footnotetext{
${ }^{36}$ P3EI Universitas Islam Indonesia Yogyakarta, Ekonomi Islam (Jakarta: PT Raja Grafindo Persada, 2008$), 332$.

37 Calvert, G. A., dan Brammer, M. J. "Predicting Consumer Behavior: Using Novel Mind-Reading Approaches", Pulse IEEE, Volume 3, Nomor 3 (2012), 38-41.
} 
perusahaan dapat mendesain produk baru mereka dengan "harapan" konsumen, baik itu pada strategi penetapan harga untuk produk baru maupun dari segi desain produk mereka.

Dalam hal penetapan harga untuk produk baru, ada strategi penetapan harga yang disebut sebagai skimming price, yakni menetapkan harga awal setinggi-tingginya dengan harapan memperoleh keuntungan yang sebesar-besarnya. Praktik tersebut pada dasarnya menyalahi prinsip etika bisnis Islam, yaitu prinsip keseimbangan. Sedangkan dalam kaitannya dengan pembuatan desain produk baru, desain produk harus memiliki keunikan tersendiri yang membedakan dengan produk lainnya. Tidak boleh ada praktek plagiasi dalam pembuatan desain produk.

Seperti dalam praktek yang dilakukan oleh perusahaan Hyundai Motor, bahwasanya mereka membutuhkan persepsi konsumen sebelum memutuskan memproduksi ribuan mobil baru. Dalam penelitian tidak ada pemaksaan oleh peneliti kepada responden menggunakan metode EEG. Dan hasil penalitian tersebut digunakan oleh perusahaan sebagai acuan untuk membuat mobil baru dengan hasil penjualan yang memuaskan.

\section{Analisis Prinsip Dasar Etika Bisnis Islam terhadap Implementasi Neuromarketing pada Brand/Merek}

Branding dan loyalitas konsumen terhadap merek pilihan mereka saling berhubungan dengan emosi yang kuat dalam proses pengambilan keputusan dibandingkan dengan merek lain. Pelanggan cenderung bertindak loyal terhadap merek pilihan mereka. Dalam kegiatan pemasaran, merek atau brand adalah aset tak berwujud (intangible asset) yang semakin mahal saja harganya. ${ }^{38}$ Brand merupakan pelabelan yang memiliki kekuatan untuk mendongkrak produk, selain itu brand juga dihubungkan dengan kepercayaan konsumen untuk memberikan jaminan kepuasan yang lebih baik.

Brand dianggap sebagai salah satu strategy marketing yang sangat efektif. Selain sebagai identitas, brand juaga akan membuat konsumen percaya dan setia terhadap merek tertentu. Ada ikatan emosi yang membuat konsumen tidak mempertimbangkan merek lain, walaupun harganya lebih murah. Ada perasaan nyaman jika tidak menggunkan merek tersebut.

Brand juga diasosiasikan dengan identitas merek. Kunci dalam membangun identitas merek yang kuat terletak pada bagaimana manajemen merumuskan identitas merek yang sejalan dengan visi perusahaan dan dapat terwujud dalam kultur dan sistem nilai yang ada. Adapun kunci dalam menjaga identitas yang terbentuk adalah selalu menjaga konsistensi kualitas dalam di setiap titik kontak merek dengan konsumen. ${ }^{39}$

Slogan dalam suatu brand harus menampilkan kualitas dan keunggulan dari brand itu sendiri tanpa menjelekkan brand lain. Akhlak Islam mengharuskan agar suatu golongan tidak menganggap golongan itu yang paling benar, juga tidak mudah menuduh kalangan lain melakukan suatu kesesatan. Menyampaikan keunggulan diri atau golongan boleh saja, tetapi tidak mengaitkannya dengan kekurangan orang atau golongan lain.

\footnotetext{
${ }^{38}$ Chairiwaty, "Branding Identity: Sebuah Tinjauan Mengenai Etika Bisnis Islam”, Jurnal Ilmu Komunikasi, Volume 2, Nomor 2 (Oktober 2012), 152.

39 Ibid., 155.
} 


\section{Kesimpulan}

Penggunaan teknologi biometrika neuromarketing mampu mengoptimalkan langkah untuk menetapkan strategi pemasaran. Penelitian neuromarketing menghilangkan subjektivitas dengan melakukan pengukuran perilaku otak yang dapat diamati. Hal ini terjadi karena 95\% dari proses keputusan membeli dilakukan di bagian otak yang menangani emosi. Tujuan neuromarketing adalah untuk mengetahui bagaimana otak secara fisiologis dipengaruhi oleh iklan dan strategi pemasaran lainnya, menggunakan bantuan alat medis seperti fMRI, EEG, eye tracking dan lain sebagainya. Neuromarketing dapat memperoleh data internal yang sangat berharga untuk membantu pemasar menetapkan strategi pemasaran yang tepat.

Adapun alat pemasaran yang dapat dikenai oleh neuromarketing, antara lain iklan, harga, pengembangan produk baru dan merek. Hasil yang didapat dapat diimplementasikan ke dalam strategi pemasaran yang terbukti secara efektif dapat meningkatkan efektivitas penjualan suatu prooduk.

Walaupun terbukti bahwa neuromarketing mampu meningkatkan efektivitas strategi pemasaran, namun ada beberapa isu mengenai prinsip dasar etika bisnis Islam yang dilanggar. Pelanggaran terhadap prinsip dasar etika bisnis Islam pada penggunaan teknologi biometrika neuromarketing, antara lain penggunaan teknologi tersebut dapat meracuni pikiran konsumen, melanggar kehendak bebas konsumen serta melanggar pedoman federal penelitian dengan subyek manusia. Dalam implementasinya, penggunaan neuromarketing juga melanggar prinsip dasar etika bisnis Islam, seperti penggunaan diskon psikologikal, penipuan terhadap iklan dan lain sebagainya.

\section{Daftar Rujukan}

al-Qaradhawi, Yusuf. Norma dan Etika Ekonomi Islam. Jakarta: Gema Insani Press, 1997. Alma, Buchari. Pengantar Bisnis. Bandung: Alfabeta, 1999.

Ardianto, Bram "Otak reptile, Sistem Limbik dan Neokorteks" dalam https://bramardianto.com/otak-reptil-sistem-limbik-dan-neokorteks.html.

Campero, LCI. Asela A. Burgos dan Jose G. Vargas Hernandes, "Analytical Approach to Neuro Marketing As a Bussines Strategy", Journal of Research in International Business and Management, Volume 2, Nomor 12 (Desember 2012).

Chairiwaty, "Branding Identity Sebuah Tinjauan Mengenai Etika Bisnis Islam", Jurnal Ilmu Komunikasi, Volume 2, Nomor 2 (Oktober 2012).

Davis, Joel J. Penelitian Periklanan Teori dan Praktik, edisi kedua. Jakarta: Rajawali Pers, 2013.

Francis, Ritty dan Reena R, "A study on Neuromarketing: A unique Bond between Consumer's Cognizance And Marketing”, International Journal of Commerce and Management Research, Volume 2, Nomor 11 (November 2016).

Kotler, Philip dan Garry Amstrong. Prinsip-Prinsip Pemasaran. Jakarta: Erlangga, 2008.

Kumar, Harit dan Priyanka Singh, "Neuromarketing: An Emerging Tool of Market Research", International Journal of Engineering and Management Research, Volume 5, Nomor 6 (2015).

Lindstrom, M. Buy-Ology Rahasia di Balik Keputusan Membeli. Jakarta: Elex Media 
Komputindo, 2011.

Madan, C. R., "Neuromarketing: The Next Step In Market Research?”, Jurnal Eureka, Volume 1, Nomor 1 (2010).

McClure, S. M. et al. "Neural Correlates of Behavioral Preference for Culturally Familiar Drinks.", Neuron, Volume 44, Nomor 2 (2004).

Milton, C.L. Ethical Issues From Nursing Theoretical Perspectives. t.t: Nursing Science Quarterly, 1999.

Morin, Christoper, "Neuromarketing: The New Sciene of Consumer Behavior", dalam www.researchgate.net/publication/226228201.

P3EI Universitas Islam Indonesia Yogyakarta. Ekonomi Islam. Jakarta: PT Raja Grafindo Persada, 2008.

Renvoise, P. dan C. Morin. Neuromarketing: Understanding The Buy Button in Your Customer Brain. Nashville Tennessee: Thomas Nelson, 2007.

Venkatraman, V. et all. "New Scanner Data for Brand Marketers: How Neuroscience Can Help Better Understand Differences in Brand Preferences", Journal of Consumer Psychology, Volume 22, Nomor 1 (2012).

Wilson, R. Mark Jeannie Gaines, dan Ronald Hill. "Neuromarketing and Consumer Will", The Journal of Consumer Affairs, Volume 42, Nomor 1 (Maret 2008). 